\section{3-Amino-1,2,4-triazole Prolongs Carnation Vase Life}

\author{
Steven A. Altman ${ }^{1}$ and Theophanes Solomos \\ Department of Horticulture, University of Maryland, College Park, MD 20742
}

Additional index words. amitrole, cut flowers, Dianthus caryophyllus, ethylene biosynthesis, senescence, computer-assisted photodocumentation

Abstract. Continuous postharvest treatment of carnation flowers (Dianthus caryophyllus L. cv. Elliot's White) with 50 or $100 \mathrm{~mm}$ aminotriazole significantly extended useful vase life relative to flowers held in distilled $\mathrm{H}_{2} \mathrm{O}$. No morphological changes symptomatic of floral senescence appeared in treated flowers until 12 to 15 days after harvest. The longevity of aminotriazole-treated flowers was extended to $\approx 18$ days. The respiratory rate of aminotriazole-treated carnations was suppressed, and they exhibited no respiratory climacteric throughout the period of observation. The responsiveness of aminotriazoletreated flowers to exogenous ethylene appeared temporally regulated. Flowers treated with $50 \mathrm{~mm}$ aminotriazole for 2 days senesced in response to application of $10 \mu \mathrm{l}$ exogenous ethylene/liter, whereas flowers treated for $\mathbf{2 4}$ days exhibited no morphological response to ethylene treatment. Chemical name used: 3-1H-amino-1,2,4-triazole-1-yl (aminotriazole).
Silver thiosulfate (STS) is extensively used by commercial cut-flower producers to extend the useful vase life of carnations and other climacteric floral crops and to protect flowers from exogenous ethylene during shipment (Reid et al., 1980; Veen, 1979). STS is expensive, relatively difficult to prepare, and is a potentially harmful heavy-metal environmental contaminant. Aminotriazole (ATA), a lowmolecular-weight heterocyclic ring compound, is currently marketed under its common name (amitrole or amizole) for use as a postemergence, nonselective, systemic herbicide. The spectrum of ATA's effects on cellular metabolism is broad and may include inhibition of catalase activity (Margoliash et al., 1960), purine biosynthesis (Lenton, 1987), mitochondrial protein biosynthesis, and imidazol-glycerol-phosphate dehydratase activity, an essential enzyme in the histidine biosynthetic pathway of bacteria and fungi (Kidd and Gross, 1984). We report here that ATA inhibits both physiological and morphological aspects of floral senescence in carnations and may serve as an alternative floral preservative for cama-

Received for publication 14 Nov. 1991. Accepted for publication 8 July 1992. We thank Linda Dallas and David Graper for invaluable assistance with greenhouse flower production. Thanks are also extended to the Landscape Architecture Computer Laboratory for assistance with computer graphics, to the Univ. of Maryland Sea Grant College for computer time, and to the Graduate School for general research support. Mention of a trademark, proprietary product, or vendor does not constitute a guarantee or warranty of the product nor imply its approval to the exclusion of other products or vendors that may be suitable. The cost of publishing this paper was defrayed in part by the payment of page charges. Under postal regulations, this paper therefore must be hereby marked advertisement solely to indicate this fact.

${ }^{1}$ Current address: Dept. of Chemical and Biochemical Engineering, Univ. of Maryland, Baltimore County Campus, 225 Technology Research Center, Baltimore, MD 21228. tions and other cut flowers.
Plant material and treatments. Freshly harvested White Sim carnations ('Elliott's White'), produced using standard horticultural practices, were obtained from Univ. of Maryland greenhouses. Twelve flowers of uniform size and appearance, with petals re- flexed $90^{\circ}$ relative to the calyx, were used in each experiment. To facilitate uptake of treatment solutions, flowers were held in darkness at $18 \mathrm{C}$ for $1.5 \mathrm{~h}$ following harvest. Aminotriazole (Sigma, St. Louis) solutions were newly prepared for each experiment in autoclaved distilled $\mathrm{H}_{2} \mathrm{O}\left(\mathrm{dH}_{2} \mathrm{O}\right)$. Just before treatment, stems were shortened to $25 \mathrm{~cm}$ and flowers were divided randomly and immediately placed into 1000 -ml foil-covered beakers containing $250 \mathrm{ml}$ of 50 or $100 \mathrm{~mm}$ ATA solution or $\mathrm{dH}_{2} \mathrm{O}$. After $2 \mathrm{~h}$ in the solution, stems were shortened to $7.0 \mathrm{~cm}$. Flowers were then weighed and transferred to individual 25$\mathrm{ml}$ Erlenmeyer flasks containing either freshly prepared ATA solution of identical concentration or $\mathrm{dH}_{2} \mathrm{O}$.

Respiratory measurement and ethylene treatment. Treated flowers were kept for respiratory monitoring in a temperature-controlled, gas-flow system incubation chamber at $18 \mathrm{C}$ in darkness. Individual flowers were sealed in 950-ml glass jars connected to a common supply of breathing-quality air through a splitter manifold. The $\mathrm{CO}_{2}$ content in the outlet stream from each jar was monitored for $30 \mathrm{~min} /$ cycle by an automatic sampling device connected to a dual channel infrared gas analyzer (model AR-600R; Anarad, Santa Barbara, Calif.). Mean gas flow through the system was maintained at $\approx 55 \mathrm{ml} \cdot \mathrm{min}^{-1}$.

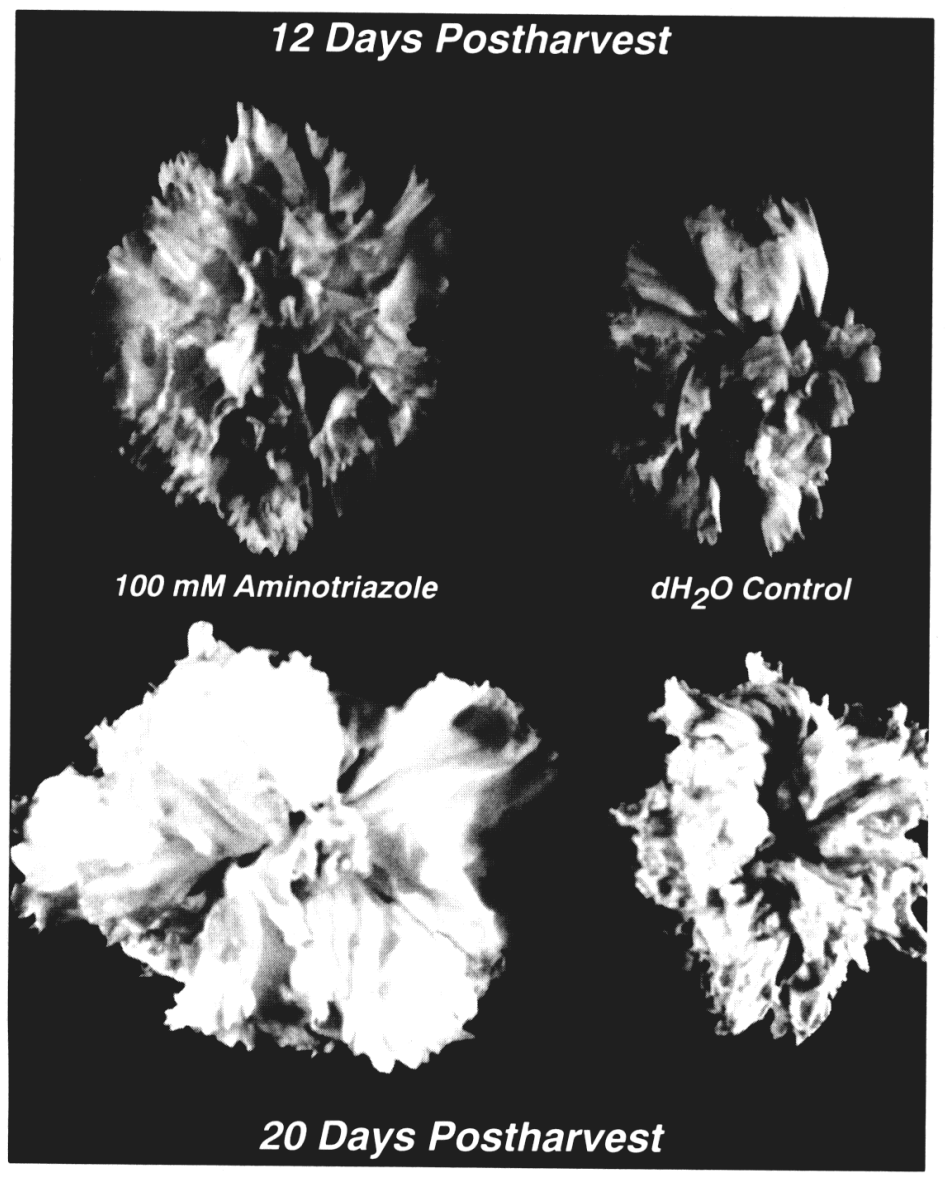

Fig. 1. Digitally processed image of the senescent morphology of $100 \mathrm{mM}$ ATA-treated carnations. Immediately following harvest, flowers were treated with ATA or $\mathrm{dH}_{2} \mathrm{O}$ and kept in darkness at $18 \mathrm{C}$. Treatment solutions were not changed during the experiment. A pair of flowers was briefly removed and photographed at 12 days postharvest. The same flowers were photographed again at the experiment's termination. 
Respiratory rates were expressed as microliters of $\mathrm{CO}_{2}$ per gram of fresh weight of tissue per hour. The effect of exogenous ethylene treatments on the vase life of flowers treated with ATA was determined by exposing flowers to $10 \mu \mathrm{C}_{2} \mathrm{H}_{4} /$ liter after either 48 or $180 \mathrm{~h}$ of ATA treatment. The latter treatment period was designed to coincide with the onset of the respiratory climacteric in nontreated control flowers. Exogenous ethylene, prepared by diluting a commercially supplied ethylene standard with breathing-quality air (Salveit and Dilley, 1987), was applied by passing a stream of air containing $10.0 \mu \mathrm{C}_{2} \mathrm{H}_{4} /$ liter over the flowers. Ethylene was monitored by gas chromatography on a gas chromatograph (model 5480A; Hewlett-Packard, Avondale, Pa.) equipped with a flame ionization detector and fitted with a $125 \times 0.32-\mathrm{cm}$ stainless steel column packed with 75 to 100 mesh activated $\mathrm{Al}_{2} \mathrm{O}_{3}$. Flowers were exposed to exogenous ethylene for $24 \mathrm{~h}$, returned to air, and photographed. All experiments were conducted four times.

Computer-assisted photodocumentation. Following each experiment, flowers were photographed against a black background on a copy/enlargement stand fitted with four 250W photoflood lights, using $35-\mathrm{mm}$ slide film (Kodak Ektachrome, ASA 100) and an 80A (dark-blue) filter. Resulting slides were scanned and digitized using a scanner (model LS-3500; Nikon Corp., Japan) and standard set-up parameters in Color Studio version 1.5 (Letraset, Paramus, N.J.) running on an Apple Macintosh IIfx computer augmented with a color monitor and graphics coprocessor board. Corresponding images from several slides were cropped and combined into a single RIFF format file. Provided software fonts were used to substitute publication-quality descriptive labels for the handwritten identification notes placed near each flower during photography. Final digitized images were output to a 300 dpi laser printer for review, to a slide Montage FR1 film recorder (Presentation Technologies, El Segundo, Calif.) for archival purposes, and to diskette for publication.

Effect of aminotriazole on carnation vase life. When applied to cut carnations as a 50- or 100-mm basal solution, ATA prolonged useful vase life, inhibiting both physiological and morphological aspects of carnation senescence relative to flowers kept in distilled deionized water. Aminotriazole-treated flowers exhibited no morphological changes typically symptomatic of carnation petal senescence for 12 to 15 days following harvest, and no petal deterioration occurred until 18 to 20 days (Fig. 1). The effects of ATA on floral longevity are similar to those previously reported for camations treated with inhibitors of ethylene action and biosynthesis (Cook and Van Staden, 1987; Veen, 1979).

Effect of aminotriazole on floral respiration. The physiological effects of ATA on carnation senescence includes a general suppression of the respiratory rate, inhibition of the respiratory climacteric, and inhibition of the climacteric increase in ethylene evolution
(Altman, 1991). An initial rapid decline in respiration was observed in flowers treated with either 50 or $100 \mathrm{~mm}$ ATA (Fig. 2). Flowers treated with $50 \mathrm{~mm}$ ATA then appeared to undergo a stabilization of respiratory activity at $\approx 72 \mathrm{~h}$ postharvest, whereas the respiratory rate of flowers treated with $100 \mathrm{~mm}$ continued to decline throughout the period of observa- tion (Fig. 2). Beginning at $96 \mathrm{~h}$ postharvest, observed differences in the respiratory rate of flowers treated with 50 or $100 \mathrm{~mm}$ aminotriazole were statistically significant $(\alpha=0.95)$.

Effect of aminotriazole on floral response to ethylene. The effect of exogenous ethylene on the senescence of treated flowers depended both on ATA concentration and the length of

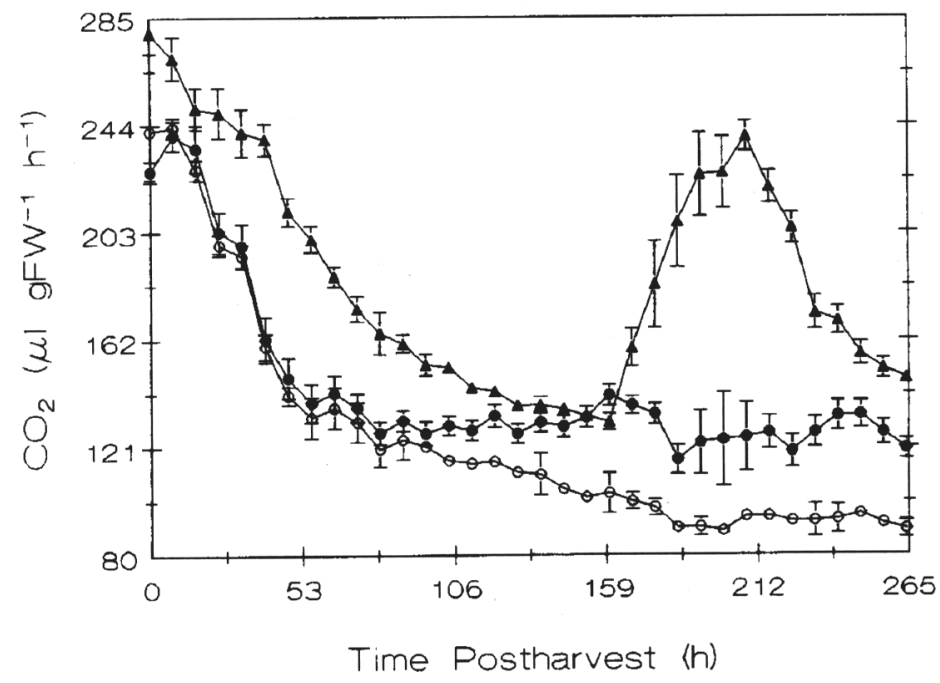

Fig. 2. Respiratory response of carnation flowers to continuous treatment with 50 ( $\bullet$ ) or 100 ( O ) mM ATA or with $\mathrm{dH}_{2} \mathrm{O}(\boldsymbol{\Delta})$. Respiration was continuously monitored by flow infrared gas analysis during the course of senescence. Bars represent $\pm 1 \mathrm{SD}$.

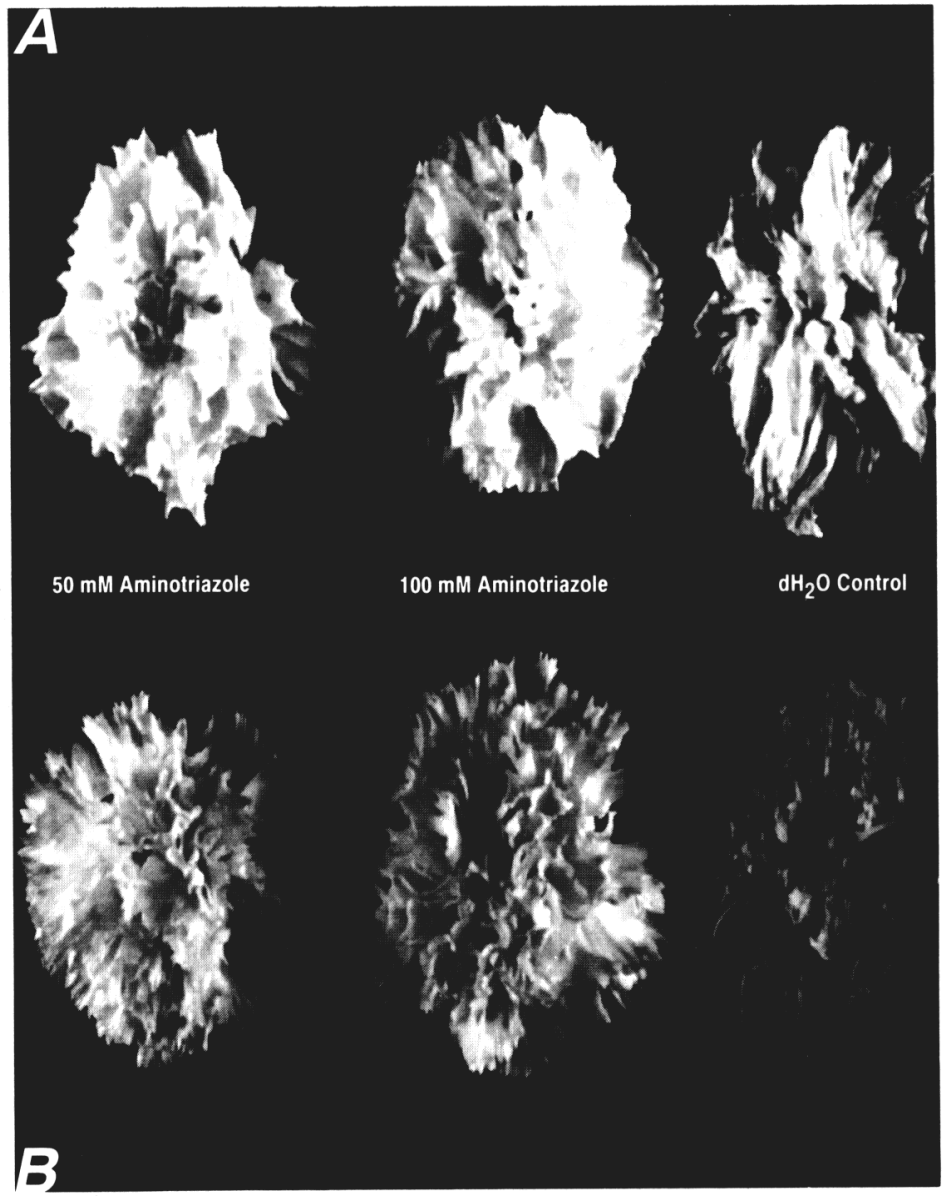

Fig. 3. Digitally processed image of the temporally mediated morphological response of carnation flowers continuously treated with 50 or $100 \mathrm{mM}$ ATA, or with $\mathrm{dH}_{2} \mathrm{O}$ followed by exposure at $48 \mathrm{~h}(\mathbf{A})$ or 180 $\mathrm{h}(\mathbf{B})$ postharvest to ethylene at a concentration of $10.0 \mu \mathrm{l} \cdot$ liter $^{-1}$. 
time flowers were treated with aminotriazole before ethylene treatment. Flowers exposed to ethylene at $10 \mu \mathrm{l} \cdot \mathrm{liter}^{-1}$ for $24 \mathrm{~h}$ following $48 \mathrm{~h}$ of treatment with either 50 or $100 \mathrm{~mm}$ ATA exhibited treatment-dependent, senescenceassociated morphological responses. Flowers treated with $50 \mathrm{~mm}$ ATA exhibited obvious morphological changes symptomatic of the initial stage of carnation senescence, including moderate petal in-rolling and decline in fresh weight. The morphological response of flowers treated with $100 \mathrm{~mm}$ aminotriazole was a slight inrolling of outer whorl petals. As expected, ethylene induced the terminal stage of senescence in nontreated control flowers (Fig. 3a). This differential morphological response to exogenous ethylene may indicate that the treatment-related difference in respiratory rate noted above is due to the incomplete inhibition of ethylene action in flowers treated with $50 \mathrm{~mm}$ ATA.

No morphological changes symptomatic of flower senescence were observed in flowers treated for $\approx 5$ to 7 days with either 50 or 100 $\mathrm{mu}$ ATA that then were exposed to ethylene at $10 \mu \mathrm{l} \cdot$ liter $^{-1}$ for $24 \mathrm{~h}$ (Fig. 3b). Between 2 to $\approx 6$ days postharvest, ATA-treated carnations appeared to lose the ability to perceive and respond to exogenous ethylene. Since ethylene was present in treated tissues at a concentration sufficient to induce a rapid response in control flowers (Altman, 1991), the effect of 5 to 7 days of ATA treatment may have been due either to repression of the synthesis of ethylene receptor molecules or that of proteins required for transduction of ethylene action.

Two systemic triazole fungicides, triadimefon (Bayleton) and propiconazole, were recently reported to have antisenescence effects in small grains and in Kentucky bluegrass (Poa pratensis L.) (Goatley and Schmidt, 1990). The chemical moiety shared in common between triazole fungicides and amino- triazole is the 1H-1,2,4-triazole-1-yl heterocyclic ring structure, implying that this structure may account for the observed and reported effects of these compounds on senescence.

The major impediment to commercial adoption of ATA as a cut-flower preservative is its classification as a putative carcinogen. Since ATA is relatively nontoxic, having both an oral and dermal $\mathrm{LD}_{50}$ (male rats) of $>5000 \mathrm{mp} /$ $\mathrm{kg}$ body weight (Sine et al., 1991), dosage levels of $1000 \mathrm{mg} / \mathrm{kg}$ body weight per day administered by stomach tube for 21 days followed by $2192 \mathrm{ppm}$ given ad libitum in the diet were required to induce hepatomas and carcinomas of the thyroid in a test population of newborn mice (Innes et al., 1969). Dosages of this magnitude were sufficient to result in deposition of crystalline ATA in liver, thyroid, and other target organs (Durham and Williams, 1972). High dose administration may result in physical damage to cells, thereby increasing the rate of mitogenesis and, indirectly, ofmutagenesis (Ames and Gold, 1990). Therefore, the validity of maximal tolerated dose toxicity evaluation procedures, such as those of Innes et al. (1969), is questionable. However, in view of ATA's ambivalent current toxicological status, a commercial application system designed to minimize handling and contact, such as a soluble capsule or packet containing a premeasured amount of compound, may be beneficial. In addition, further research to test the effects of ATA on other commercially important cut-flower crops is required.

\section{Literature Cited}

Altman, S.A. 1991. Catalase activity, protein accumulation, and expression during senescence of carnations and in response to inhibitors of ethylene synthesis or action. PhD Diss., Univ. of Maryland, College Park.
Ames, B.N. and L.S. Gold. 1990. Too many rodent carcinogens: Mitogenesis increases mutagenesis. Science 249:970-971.

Cook, E.L. and J. Van Staden. 1987. Silver action in the cut carnation flower. Plant Physiol. Biochem. 25:485-492.

Durham, W.F. and C.H. Williams. 1972. Mutagenic, teratogenic, and carcinogenic properties of pesticides. Annu. Rev. Entomol. 17:123148.

Goatley, J.M. and R.E. Schmidt. 1990. Anti-senescence activity of chemicals applied to Kentucky bluegrass. J. Amer. Soc. Hort. Sci. 115:654656.

Innes, J.R.M., B.M. Ulland, M.G. Valerio, L. Petrucelli, L. Fishbein, E.R. Hart, I. Pallotta, R.R. Bates, H.L. Falk, J.J. Gart, M. Klein, I. Mitchell, and J. Peters. 1969. Bioassay of and industrial chemicals for tumorigenecity in mice: A preliminary note.J.Natl. Cancer Inst. 42:11011114.

Kidd, G.L. and S.R. Gross. 1984. Specific regulatory interconnection between the leucine and histidine pathways of Neurospora crassa. J. Bacterial. 158:121-127.

Lenton, J.R. 1987. Mode of action of triazole growth retardants and fungicid-A progress report. News Bul., Brit. Plant Growth Regulat. Group 9:1-12.

Margoliash, E., A. Novogrodsky, and A. Schejter. 1960. Irreversible reaction of 3-amino-1:2:4triazole and related inhibitors with the protein of catalase. Biochem. J. 73:339-350.

Reid, M.S., J.L. Paul, M.B. Faroomand, M. Kofranek, and G.L. Staby. 1980. Pulse treatments with silver thiosulfate complex extend the vase life of cut carnations. J. Amer. Soc. Hort. Sci. 105:2527.

Saltveit, M.E. and D.R. Dilley. 1987. Simple procedare for preparing dilute concentrations of ethylene in air or oxygen in high pressure cylinders. HortScience 12:252-253.

Sine, C., N. Fisher, and F. Valahovski. 1991. Farm chemicals handbook. 1991 ed. Meister Publishing, Willoughby, Ohio. p. C20.

Veen, H. 1979. Effects of silver on ethylene synthesis and action in cut carnations. Planta 145:467470 . 